\title{
Corporate Social Responsibility Effect on Human Right Standards and Sustainability and Csr Effect on Various Indian Corporate
}

\author{
Poonam Lakra \\ Assistant Professor: Bhagini Nivedita College (University Of Delhi) Delhi-110043, India.
}

\begin{abstract}
Every business have a main aim to earn maximum profit but there are certain social responsibilities which have to be taken care and when a corporate do these type of activities then that is called corporate socially responsible. This paper focus on CSR activities of various Indian companies and how the CSR activities prove to be a benefit or a burden for business activities. CSR can not only refer to the compliance of human right standards, labor and social security arrangements, but also to the fight against climate change, sustainable management of natural resources and consumer protection A number of companies with good social and environmental records indicate that CSR activities can result in a better performance and can generate more profits and growth but same time more important activities lacking behind when corporate focus more on CSR.
\end{abstract}

Keywords: Corporate Social Responsibility (CSR), Human right standards, Sustainability.

\section{Introduction}

In the new Companies Bill that was passed in the Indian Lok Sabha towards the fag end of the winter session, it is precisely the Clause 470 of the Bill that aroused interest and skepticism in equal measures. As per the clause it has been made mandatory for corporates that make an average profit of at least Rs. 5 crore or have a worth exceeding Rs. 500 crore, or their turnover exceeds Rs. 1,000 crore in the last three years to spend $2 \%$ of the net profit on CSR. A report by SMC Global Securities Limited states that in the last financial year the combined net profit of listed companies in India was to the tune of Rs. 4, 37,167 crores, at 2\% the CSR kitty amounts to Rs. 8,700 crores. The March issue of Forbes India categorically states that the government expects Rs 63 billion to flow in from India's top 500 listed companies, going by the government's $2 \%$ norm. If this list is further expanded to the top 1,000 corporations, add MNCs, co-operative banks and SMEs, and then we are talking about at least Rs 120 billion. Undoubtedly such a large sum generated year on year has the potential to alleviate many social as well as environmental issues ailing the nation.

\section{Meaning Of Csr}

The voluntary compliance of social and ecological responsibility of companies is called Corporate Social Responsibility (CSR).The concept of Corporate Social Responsibility was first mentioned 1953 in the publication 'Social Responsibilities of the Businessman' by William J. Bowen. However, the term CSR became only popular in the 1990s, when the German Betapharm, a generic pharmaceutical company decided to implement CSR. The generic market is characterized by an interchangeability of products. In 1997 a halt in sales growth led the company to the realization that in the generic drugs market companies could not differentiate on price or quality. This was the prelude for the company to adopt CSR as an expression of the company's values and as a part of its corporate strategies. By using strategic and social commitment for families with chronically ill children children, Betapharm took a strategic advantage Corporate social responsibility is basically a concept whereby companies decide voluntarily to contribute to a better society and a cleaner environment. Corporate social responsibility is represented by the contributions undertaken by companies to society through its business activities and its social investment. This is also to connect the Concept of sustainable development to the company's level.

\section{Benefits Of Csr}

- it help in improving financial performance,

- enhanced brand image and reputation,

- increased customer loyality and sales

- increased ability to attract and retain employees

- easier assess to capital

- help to improve employees moral and motivation 
- help in complying govt. statutory regulation

\section{Focus Of Various Indian Corporate`S On Csr}

How a company perceives its societal responsibility depends on various factors such as the markets in which it operates, its business line and its size. In recent years CSR has become a fundamental business practice and has gained much attention from the management of large international companies. They understand that a strong CSR program is an essential element in achieving good business practices and effective leadership. Companies have explored that their impact on the economic, social and environmental sector directly affects their relationships with investors, employees and customers. So far Corporate Social Responsibility was mainly promoted by a number of large or multinational companies, it is now also becoming important to small national companies. Indian corporate led by Tata's and Birla's have been voluntarily investing in CSR. Hence, the provision to make CSR spending mandatory is more of an intrusion and it is apparent that by doing so the government is trying to abdicate itself of its social responsibilities. Will not the mandatory provision disrupt the business plans of a many companies? Going by an ETIG research, India Inc will have to scramble to meet the target as only two companies in the Nifty - Ambuja Cement and ITC - currently spend 2\% of net profit towards CSR. While not all Tata group companies have disclosed their expenditure on CSR, Tata Steel's sustainability report mentions that the Tata group companies spend $4 \%$ of their net profit towards CSR. In fact, the new imposition takes out the sanctity of CSR making it more of a forced exercise and more so a new form of tax on profits.

In India there are an existent but small number of companies which practice CSR. This engagement of the Indian economy concentrates mainly on a few old family owned companies, and corporate giants such as the Tata and Birla group companies which have led the way in making corporate social responsibility an intrinsic part of their business plans. These companies have been deeply involved with social development initiatives in the communities surrounding their facilities. Jamshedpur, one of the prominent cities in the northeastern state of Bihar in India, is also known as Tata Nagar and stands out at a beacon for other companies to follow. Jamshedpur was carved out from the jungle a century ago. TATA's CSR activities in Jamshedpur include the provision of full health and education expenses for all employees and the management of schools and hospitals. In spite of having such life size successful examples, CSR in India is in a very nascent stage.

Activities of various Indian corporates towards CSR(such as Tata moters, Reliance power, Hindustan unilever, Ambuja cements etc.)

- Aditya Birla Group, Tata Motors, LICI emerge as the top three corporates in the Nielsen's Corporate Image Monitor 2012-2013

- ITC Ltd, ABG, Infosys, TATA Steel and TATA Motors are the corporates seen most actively involved in CSR activities

Aditya Birla Group tops the latest round of Nielsen's Corporate Image Monitor 2012-13 survey that measures the reputation of leading corporates in the country. Tata Motors comes $2^{\text {nd }}$, followed by Life Insurance Corporation of India $\left(3^{\text {rd }}\right)$ and ITC Ltd $\left(4^{\text {th }}\right)$, while Infosys and Wipro are tied at the fifth spot.Aditya Birla Group has emerged 'Best in Class' across all the six pillars of Corporate Image, according to the annual Corporate Image Monitor 2012-13, conducted by Nielsen, a leading global provider of insights and information into what consumers watch and buy. The six pillars of Corporate Image comprise ofProduct \& Service quality, Vision and Leadership, Workplace Management, Financial Performance, Operating style and Social responsibility. Tata Motors also shares space with ABG as the 'Best in Class' for 'Product \& Service quality'and 'Vision and Leadership'.

\section{Arguments Regarding Csr}

Corporate social responsibility earlier a voluntary task but now a day it become a mandatory for certain organizations as mention above. Due to such mandatory requirement certain arguments raise in favour and in against of CSR. Does it not make sense that corporations take up social responsibilities on a voluntary basis rather than making it mandatory? Those in support of the move argue that by mandating CSR in the Companies Bill, the government has created a process whereby companies are forced to spend on social returns along with financial returns and they are forced to report on such spends. Such a mandatory provision, however noble its intentions may be, could lead to irregularities in revenue accounts and perhaps more corruption. The other point worth considering is will not the mandatory clause give government officials a strong tool to harass companies. Jagannadham Thunuguntla, Strategist \& Head of Research, SMC Global Securities Limited, says "While the objective behind CSR is noble, but proper system and procedures need to be implemented for effective usage of such massive amount. Else, there is always a risk of misusage of noble intentions." 
Is there a way out? There are a few who argue that if the government wants, it can increase the rate of corporate tax to 32 percent from the current 30 percent rather than making it mandatory for companies to spend $2 \%$ on CSR. According to media reports, a number of companies are lobbying for tax breaks on CSR investment.

\section{Burden Side Of Csr}

Over the last years an increasing number of companies worldwide started promoting their Corporate Social Responsibility strategies because the customers, the public and the investors expect them to act sustainable as well as responsible. In most cases CSR is a result of a variety of social, environmental and economic pressures.

There is another danger too: namely, that CSR will distract attention from genuine problems of business ethics that do need to be addressed. These are not in short supply. To say that CSR reflects a mistaken analysis of how capitalism serves society is certainly not to say that managers can be left to do as they please, nor to say that the behavior of firms is nobody's concern but their own. There is indeed such a thing as "business ethics": managers need to be clear about that, and to comprehend what it implies for their actions. Also, private enterprise serves the public good only if certain stringent conditions are met. As a result, getting the most out of capitalism requires public intervention of various kinds, and a lot of it: taxes, public spending, regulation in many different areas of business activity. It also requires corporate executives to be accountable - but to the right people and in the right way.

CSR cannot be a substitute for wise policies in these areas. In several little-noticed respects, it is already a hindrance to them. If left unchallenged, it could well become more so. The thinking behind CSR does not meet that test.The new imposition takes out the sanctity of CSR making it more of a forced exercise and more so a new form of tax on profits

\section{Csr Effect On Human Right And Standards And Sustainability}

What do human rights standards have to do with CSR?

Human rights are relevant to the economic, social and environmental aspects of corporate activity. For example, labour rights requiring companies to pay fair wages affect the economic aspect. Human rights such as the right to non-discrimination are relevant to the social aspect. And the environmental aspects of corporate activity might affect a range of human rights, such as the right to cleanliness and safe drinking water.

So, while the primary responsibility for the enforcement of international human rights standards lies with national governments, there is a growing acceptance that corporations also have an important role to play.

Corporations impact on human rights in significant ways. These impacts have increased over recent decades as the economic might and political influence of corporations has grown, and as corporations have become more involved in delivering services previously provided by governments.

Corporations have come to recognise that part of being a good corporate citizen includes respecting the human rights of those who come into contact with the corporation in some way. This might be direct contact (for example, employees or customers), or indirect contact (for example, workers of suppliers, or people living in areas affected by a corporation's activities).

Corporations are also responding to the fact that many consumers and investors expect corporations to act in a socially responsible manner. The extent to which a company implements a comprehensive CSR program can influence consumer and investor decisions.

\section{Csr And Sustainability}

1 Corporate Social Responsibility and Sustainability is a company's commitment to its stakeholders to conduct business in an economically, socially and environmentally sustainable manner that is transparent and ethical. Stakeholders include employees, investors, shareholders, customers, business partners, clients, civil society groups, Government and non-government organisations, local communities, environment and society at large.

2 Corporate Social Responsibility and Sustainability is essentially a way of conducting business responsibly. 'Corporate responsibility' is integral to corporate social responsibility. Implicit in this premise that business should be conducted responsibly, are several expectations from corporate enterprises.

3 Corporate enterprises are expected to conduct their business operations and activities in a socially responsible and sustainable manner at all times. Even routine business activities not funded from the CSR and Sustainability budget, should aim at creating new business opportunities and developing new products and services that are affordable for the consumers, profitable for the companies, and help in contributing to socio-economic development and environment protection.

4 Enterprises should integrate and align their CSR and Sustainability policies and activities with their business goals, plans and strategies. 
5 Mandatory compliance with legal requirements / rules / regulations / laws in letter and in spirit will be covered under CSR and Sustainability activity. However, expenditure on such activities would not be covered by CSR's financial component and would be considered as mainstream business spend.

6 The philosophy and spirit of corporate social responsibility and sustainability should get embedded in the core values of all the CPSEs, be imbibed by the employees at all levels and it should permeate into all the activities, processes, operations and transactions of the enterprise. For this, the personal involvement, drive, passion and zeal of the top management, including the CEO of the public enterprise is essential to spread the message of CSR and Sustainability within the organisation and to ensure the committed involvement of all employees in carrying forward the agenda of CSR and Sustainability.

7 Each Enterprises shall have a Board level committee headed by either the Chairman and / or Managing Director, or an Independent Director to oversee the implementation of the CSR and Sustainability policies of the Company and to assist the Board of Directors to formulate suitable policies and strategies to take the CSR and Sustainability agenda of the company forward in the desired direction.

8 To facilitate co-ordination of CSR and Sustainability initiatives of different departments within the organisation, to report on their separate endeavours, to issue policy directives on the subject, and to devise an appropriate corporate communication strategy in this regard, it is expected that the public sector enterprises will appoint a fairly senior officer not less than one rank lower to the Board level to function as the nodal officer. The designated nodal officer is expected to have a team of officials to assist him / her in co-ordination work, which will in way detract from the importance of CSR and Sustainability work in which all the supervisory staff in all departments would be continuously engaged in. The composition of the team of officials constituted to assist the nodal officer is to be decided by the Board of Directors, or the Board level committee. The designated nodal officer will regularly submit reports regarding the progress in the implementation of CSR and Sustainability activities to the Board level committee.

9 The Board level committee and the designated nodal officer's team of officers together will constitute the two-tier organisational structure to steer the CSR \& Sustainability agenda of the company.

10 Enterprises are expected to have knowledge about their important stakeholders, and be aware of their expectations of how business should be conducted. They should devise mechanisms for regular dialogue and consultation with key stakeholders, especially to ascertain their views and priorities regarding the selection and implementation of CSR and Sustainability activities. Though, the ultimate discretion in the selection and implementation of CSR and Sustainability activities is that of the Board of Directors of a company who take the decision in the best interest of the organisation, keeping in view the organisational capability, resource capacity and core competence of the enterprise.

11 CSR and Sustainability policies should address social, economic and environmental concerns and in the selection of activities the focus should be on the social, economic and environmental impact thereof, rather than mere output or outcomes. Activities which are ad hoc and philanthropic in nature should be avoided. In fact, impact assessment of CSR and Sustainability initiatives may get greater weightage in performance $(\mathrm{MoU})$ evaluation after completion of the project / activities, than mere certification of having utilized the earmarked budget, or even rigid adherence to timelines. CPSEs are encouraged to join hands and pool their resources and capabilities to create synergy for undertaking joint ventures for projects which have scalability and greater social impact that can trigger socio-economic development through ripple effects.

12 CPSEs should refrain from taking up activities which are clearly mandated to be performed by the Government and / or for which Central / State Government's schemes have been sanctioned, as it could result in unnecessary duplication. However, the CPSEs can supplement the efforts of the Government in crossing the 'last mile' for achieving the targets / goals, if it is accurately assessed that the resource gap and inadequate capacities are critical constraints in achieving the targets / goals of a particular government scheme / initiative / welfare project. Here also, duplication in allocation of funds must be strictly avoided.

13 Ethical conduct of business lies at the core of responsible business. To promote organisational integrity it is essential that premium is placed on individual probity of employees; transparency in all activities, dealings and transactions is encouraged; unethical, corrupt and anti-competition practices are discouraged; temptation of quick returns and marginal gains in business through questionable means is resisted; and, positions and situations that give rise to possible conflict of interest are avoided. The corporate enterprises are expected to subject their performance to scrutiny and audit by external agencies. As a part of their corporate social responsibility they should resort to public disclosure of all information for the benefit of all stakeholders. The companies should disclose their CSR and Sustainability initiatives on their official websites. A brief summary of CSR \& Sustainability activities should also be included in their Annual Report.

14 Public sector enterprises, especially those having global operations and dealings are encouraged to adopt global standards as these are increasingly becoming a requirement for testifying credentials of companies 
having global presence, and standardised reporting and systematised documentation makes comparison of performance easier. Such companies are also advised to practice CSR and Sustainability policies as applicable to the conditions prevailing in the host countries where they carry out their business operations.

15 In their concern for social and environment sustainability, corporate enterprises professing to behave responsibly, are expected to produce goods and services that are safe and healthy for the consumers and the environment, with reduced cost to the company in the long run. They are expected to effectively use the services of their R\&D departments in leveraging technology for production of goods and services which are resource efficient, consumer friendly and environmentally sustainable throughout their life cycles. Educating the consumers and spreading awareness about the handling, usage and advantages of the ecofriendly products and influencing consumer preference for such products is what is expected of responsible business.

16 In brief, it is generally expected that socially responsible public sector enterprises would take initiatives to: i) promote organisational integrity and ethical business practices through transparency in disclosure and reporting procedures,

ii) leverage green technologies, processes and standards to produce goods and services that contribute to social and environment sustainability,

iii) contribute to inclusive growth and equitable development in society through capacity building measures, empowerment of the marginalised and underprivileged sections/communities.

iv) promote welfare of employees and labour (casual or contractual), by addressing their concerns of safety, security, professional enrichment and healthy working conditions, whether mandated or otherwise. However, expenditure on mandated activities cannot qualify for CSR's financial components. Central Public Sector Enterprises should formulate policies which meet the expectations of the stakeholders, within their organisational resource capability.

\section{Suggestive Measures For Better Appilaction Of Csr}

But this is not the end of the matter. Particular CSR initiatives may do good, or harm, or make no difference one way or the other, but it is important to resist the success of the CSR idea-that is, the almost universal acceptance of its premises and main lines of argument. Otherwise bones may indeed begin to snap and CSR may encroach on corporate decision-making in ways that seriously reduce welfare.

Private enterprise requires a supporting infrastructure of laws and permissions, and more generally the consent of electorates, to pursue its business goals, whatever they may be. This is something that CSR advocates emphasise - they talk of a "licence to operate" - and they are quite right. But the informed consent of electorates, and an appropriately designed economic infrastructure, in turn require an understanding of how capitalism best works to serve the public good. The thinking behind CSR gives an account of this which is muddled and, in some important ways, downright false.In essence CSR should be done with passion and dedication, and not because it is thrust upon.

As companies face themselves in the context of globalization, they are increasingly aware that Corporate Social Responsibility can be of direct economic value. Although the prime goal of a company is to generate profits, companies can at the same time contribute to social and environmental objectives by integrating corporate social responsibility as a strategic investment into their business strategy. To guarantee the supply of responsible and ethical goods, it is especially important to implement a nationwide system of CSR standards.The OECD Guidelines for multinational Enterprises and the ILO - International Labour Standards form the principles for the societal responsibility of companies and will help to implement CSR on the international level.

\section{Conclusion}

CSR effect almost all the aspects of the corporation such as human, social, ethical and in the world of globalization CSR can be of economic value along with profit maximization object. Corporate have to be socially responsible and they have to integrate there activities towards CSR. Along with burden side CSR has a benefit side also and It is not a short term phenomena it will definitely help in the long run sustainability.

\section{References}

[1]. Backhaus-Maul, Holger (2006), Gesellschaftliche Verantwortung von Unternehmen, Bundeszentrale für politische Bildung.

[2]. Bundesministeriums für Umwelt, Naturschutz und Reaktorsicherheit (BMU), Corporate Social Responsibility - gesellschaftliche Verantwortung von Unternehmen.

[3]. CSR in Deutschland, Internetportal zum Thema CSR.

[4]. Diromualdo, Tony corporate social responsibility-burden, sham or golden opportunity

[5]. DIE, Corporate Social and Environmental Responsibility in India - Assessing the UN Global Compact's Role (PDF 603 KB, english)CSR Asia

[6]. En.reset.org 
[7]. Global Compact (2008), Annual Review 2008

[8]. Hamann, Götz/ Heuser, Uwe Jean (2008), Soziale Verantwortung. Können Unternehmen gut sein? in: Die Zeit.

[9]. Keeler, Dan (2003), Shaping Up, in: Gobal Finance Magazine.

[10]. Konrad, Astrid (2006), "CSR": Zur Verantwortung von Unternehmen, in: derStandard.at.

[11]. Leitl, Michael (2009), Was ist ... Corporate Social Responsibility? In: Harvard Business Manager.

[12]. Loew, Thomas/ Ankele, Kathrin/ Braun, Sabine/ Clausen, Jens (2004), „Die Bedeutung der CSR-Diskussion für Nachhaltigkeit und die Anforderungen an Unternehmen“.

[13]. Loew, Thomas/ Clausen, Jens, Loft, Lasse/ Braun, Sabine (2009), Fallstudien zu CSR und Innovation: Praxisbeispiele aus Deutschland und den USA

[14]. Nationales CSR-Forum, Gemeinsames Verständnis von CSR in Deutschland.

[15]. Rat für Nachhaltige Entwicklung (RNE) (2005), Wegweiser Nachhaltigkeit 2005.

[16]. Rat für Nachhaltige Entwicklung (RNE) (2006), Unternehmerische Verantwortung in einer globalisierten Welt - Ein deutsches Profil der Corporate Social Responsibility.

[17]. Rat für Nachhaltige Entwicklung (2008), Nachhaltigkeit und CSR zahlen sich aus.

[18]. Sinico, Sean (2007), Wie viel soziale Verantwortung haben Unternehmen? - Ein Vergleich.

[19]. Weber, Corina (2006), Unternehmen. Experten für den guten Ruf, in: Die Zeit.

[20]. www.dpemou.nic

[21]. www.humanrights.gov.au

[22]. www.nielsen.com

[23]. www.peoplematters.in 